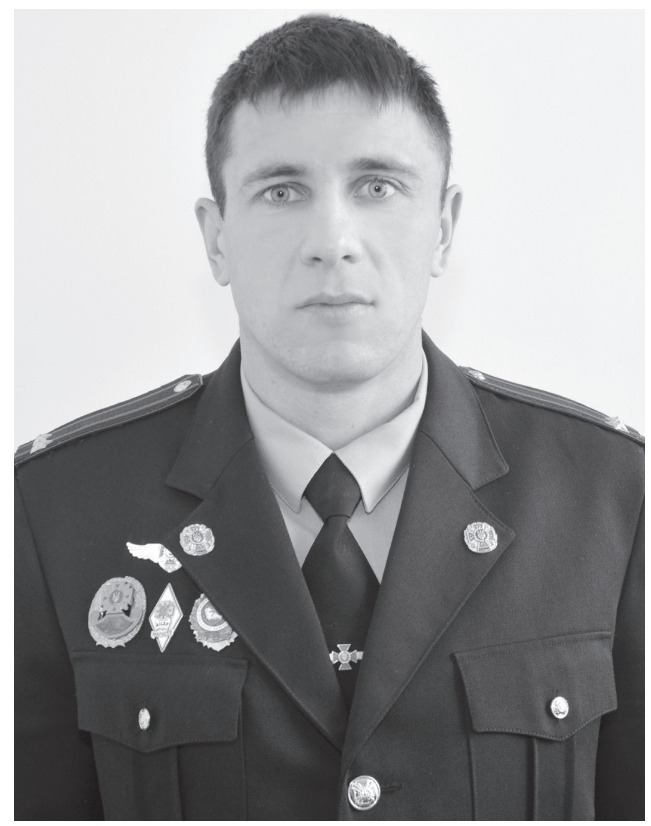

Вавренюк Сергей Анатольевич,

водственного иентра Наиионального университета гражданской защиты Украины, 61023, г. Харьков, ул. Чернышевская, 94, (057) 700-31-71, e-mail: sergei-vaचrenyиk@ писzи.еdи.иа

ORCID: 0000-0002-6396-9906

\title{
INFLUENCE OF THE PROCESS OF REFORMING THE HIGHER EDUCATION OF UKRAINE ON THE HEALTHY LIFESTYLE OF STUDENT YOUTH
}

Abstract. This article reveals the features of the impact of the process of reforming higher education on the healthy lifestyle of students during their studies in higher educational institutions.

The article analyzes the practice of forming a healthy lifestyle of student youth in the context of reforming the higher education system of Ukraine, the indicated conditions for using a competency-based approach to the formation of a healthy lifestyle, and discusses the methods of interaction of subjects in the educational space of higher educational institutions.

The article explains the reasons for the awareness in the education of a healthy lifestyle of student youth.

Much attention is paid in the article to the criteria that ensure the formation of a healthy lifestyle of students. Youth health issues are considered in the format 
of a competency-based approach in which a future specialist acquires a number of general cultural competencies during his studies at a higher educational institution.

In addition, the author identifies a number of tasks aimed at creating a healthy lifestyle for students in higher education institutions, focuses on tasks for teachers.

The article notes the methods necessary for the implementation of the program in higher education institutions for the formation of a healthy lifestyle, which increase the effectiveness of the information and educational tools of higher education institutions when forming the need for students in constant physical education and sports.

The author comes to the conclusion that health, as a complex integral state, is characterized by the presence of knowledge, skills in health-preserving activities, which encourages students to self-develop and self-educate, and to adapt them in the context of reforming the higher education system.

In conclusion, the author says that the formation of a healthy lifestyle of a future specialist as one of the strategic areas of training in higher education institutions requires raising a question from the perspective of considering the possibilities of the educational process to ensure such an event and the attitude to future activities that would determine its value orientations for healthy lifestyle.

Keywords: higher education, educational space, competency-based approach, students, reforming higher education, healthy lifestyle.

\section{ВПЛИВ ПРОЩЕСУ РЕФОРМУВАННЯ ВИЩОЇ ОСВІТИ УКРАЇНИ НА ЗДОРОВИЙ СПОСІБ ЖИТТЯ СТУДЕНТСЬКОЇ МОЛОДІ}

Анотація. Розкрито особливості впливу процесу реформування вищої освіти на здоровий спосіб життя студентів під час навчання в закладі вищої освіти.

Проведено аналіз практики формування здорового способу життя студентської молоді в умовах реформування системи вищої освіти України, сформовані умови використання компетентнісного підходу до формування здорового способу життя, розглянуті методи взаємодії суб'єктів в освітньому просторі закладів вищої освіти.

Пояснюються причини усвідомлення важливості виховання здорового способу життя у студентської молоді.

Велика увага приділяється критеріям, які забезпечують формування здорового способу життя студентів. Питання здоров'я молоді розглядається у форматі компетентнісного підходу, при якому майбутній фахівець за час навчання в закладі вищої освіти набуває ряд загальнокультурних компетенцій.

Окрім цього автор виокремлює низку завдань, які спрямовані на формування здорового способу життя студентів в рамках закладів вищої освіти, зупиняється на завданнях для педагогічних кадрів.

Наголошуються методи, необхідні для реалізації програми в закладах вищої освіти по формуванню здорового способу життя, які уможливлюють підвищення ефективності інформаційних та освітніх засобів закладу вищої 
освіти при формуванні потреби у студентської молоді в постійних заняттях фізичною культурою та спортом.

Автор доходить висновку, що здоров’я, як складний інтегральний стан, характеризується наявністю знань, умінь та навичок зі здоров’язберігаючої діяльності, котра спонукає до саморозвитку та самоосвіти студентів, їх адаптацію в умовах реформування системи вищої освіти.

У висновку автор говорить про те, формування здорового способу життя майбутнього фахівця як одного із стратегічних напрямів підготовки в закладі вищої освіти вимагає постановки питання з позиції розгляду можливостей освітнього процесу по забезпеченню такого заходу та ставлення до майбутньої діяльності, які б визначали його ціннісні орієнтири на здоровий спосіб життя.

Ключові слова: вища освіта, освітній простір, компетентнісний підхід, студентська молодь, реформування вищої освіти, здоровий спосіб життя.

\section{ВЛИЯНИЕ ПРОЦЕССА РЕФОРМИРОВАНИЯ ВЫСШЕГО ОБРАЗОВАНИЯ УКРАИНЫ НА ЗДОРОВЫЙ ОБРАЗ ЖИЗНИ СТУДЕНЧЕСКОЙ МОЛОДЕЖИ}

Аннотация. Раскрыты особенности влияния процесса реформирования высшего образования на здоровый образ жизни студентов во время обучения в высших учебных заведениях.

Проведен анализ практики формирования здорового образа жизни студенческой молодежи в условиях реформирования системы высшего образования Украины, указанные условия использования компетентностного подхода к формированию здорового образа жизни, рассмотрены методы взаимодействия субъектов в образовательном пространстве высших учебных заведений.

Объясняются причины осознание в воспитании здорового образа жизни студенческой молодежи.

Большое внимание уделяется критериям, которые обеспечивают формирование здорового образа жизни студентов. Вопросы здоровья молодежи рассматриваются в формате компетентностного подхода, при котором будущий специалист за время обучения в высшем учебном заведении приобретает ряд общекультурных компетенций.

Кроме этого автор выделяет ряд задач, направленных на формирование здорового образа жизни студентов в рамках высших учебных заведений, останавливается на задачах для педагогических кадров.

Отмечаются методы, необходимые для реализации программы в учреждениях высшего образования по формированию здорового образа жизни, которые повышают эффективность информационных и образовательных средств учреждения высшего образования при формировании потребности в студенческой молодежи в постоянных занятиях физической культурой и спортом.

Автор приходит к выводу, что здоровье, как сложное интегральное состояние, характеризуется наличием знаний, умений и навыков по здоровьесбе- 
регающей деятельности, которая побуждает к саморазвитию и самообразованию студентов, их адаптации в условиях реформирования системы высшего образования.

В заключении автор говорит о том, что формирование здорового образа жизни будущего специалиста как одного из стратегических направлений подготовки в высших учебных заведениях требует постановки вопроса с позиции рассмотрения возможностей образовательного процесса по обеспечению такого мероприятия и отношение к будущей деятельности, которые бы определяли его ценностные ориентиры на здоровый образ жизни.

Ключевые слова: высшее образование, образовательное пространство, компетентностный подход, студенты, реформирования высшего образования, здоровый образ жизни.

Problem statement. Today, along with the current problems in the higher education system of Ukraine, an important place is occupied by the formation of a healthy lifestyle of student youth, since the lack of professional orientation in the future reduces the effectiveness in practical activity. Studying at a higher education institution has specific features, namely, most students study theoretically, while maintaining a sedentary lifestyle, which is associated with high psycho-emotional and nervous overload, which are reflected in the health of students. In this regard, one of the main tasks of the educational process today is the development of education in a culture of health and a healthy lifestyle as an integral part of professional culture.

According to many scientists, health and healthy lifestyles should be considered as important qualities that encourage professionalism and successful professional activity. At the same time, the ability to take care of one's own health, to follow the principles of a healthy lifestyle is considered as a personal quality of each person in the educational process, since it provides the need for social and professional self-determination. A healthy lifestyle in the process of becoming a person is of particular importance, as it is a factor of success in educational and future professional activity. As a result, in the student years it is necessary to ensure awareness of the importance of a healthy lifestyle as a factor in the recovery of the organism after hard work [1].

Analysis of recent publications on research issues. Problems of formation of healthy way of life of student youth at the stage of reforming of the modern system of higher education of Ukraine were addressed by famous scientists: S. M. Dombrovskaya, S. V. Kirilenko, V. M. Kopa, T. M. Titarenko, K. A. Shulyak. Common approaches to defining the state policy of promoting health and ensuring a healthy lifestyle of student youth were studied by Ukrainian scientists O. Vakulenko, O. Yaremenko, and Y. Galustyan. In their writings, they considered the problems of forming a healthy lifestyle in the learning pro- 
cess, methods and ways of influencing students' minds and instilling in them a relation to sports and healthy lifestyles.

Purpose of the article. The purpose of this article is to shed light on pressing issues regarding healthy student lifestyles and to find ways of influencing higher education in the mindset of students in their own health.

Presenting the main material of research. Addressing the problem of preserving and promoting the health of student youth is an important task for many public and private sector entities. A healthy lifestyle is of particular importance in the development of the individual, as it is a factor of success in the educational and future professional activity, which is why it is necessary to ensure the awareness of the importance of a healthy lifestyle in the student years, as well as to ensure that every student is not only a professional in their field. knowledge, but also a person with the skills and organization of a healthy lifestyle as a factor in the recovery of the body after hard work.

Health as a concept today is changing its status in the public and individual consciousness not only because of belonging to a biological or social space, but also due to the presence of a spiritual and moral component in the younger generation. It is from this standpoint that the health of the individual as a value requires an explanation of the physical, moral, socio-economic, aesthetic, psychophysiological, psychological and pedagogical aspects, systematic consideration of interrelated elements that will allow to clarify their internal structure, mechanisms of influence on the behavior of student youth [2].
Among the criteria that indicate the formation of a healthy lifestyle, it is customary to highlight the following indicators:

1. The need of a person for a healthy lifestyle, which is the orientation of the individual to create a healthy lifestyle, an understanding of the important way of life and confidence in self-improvement on these issues.

2. The presence of the level of theoretical training, which is represented in the complex of knowledge, cognitive activity and the formation of analytical thinking.

3. Adequate level of technological readiness to be able to predict activities and their results in terms of healthy lifestyles and safety in general. This includes the level of ownership of ways and methods of reducing the negative impact of the environment on human health, as well as the possession of decision-making technology in any emergency.

4. The presence of creative activity while ensuring a healthy lifestyle. Such a criterion is the ability of a person to see problems, to have non-standard thinking and to be able to perceive innovations in the field of healthy lifestyles [3].

In modern conditions of society development, a specialist requires high qualification, competence, orientation in related fields of activity, social and professional mobility, ability to work effectively at the level of world standards, to think in a modern way. The professional formation of a person in the process of studying at a higher education institution and mastering the chosen profession is of particular interest and also allows to distinguish the 
professional-personal context of studying the problem under consideration, which reflects the development and formation of a person who is oriented towards high professional achievements.

As our country moves to the European integration process, the requirements for higher education are increasing, which in turn leads to constant visits to higher education institutions by students and does not sufficiently give the opportunity to pay attention to their own health. Permanent employment in terms of theoretical training, preparation for classes reduces the time for physical activity and support for their own health. Accordingly, in these circumstances, the integration of the process of forming a healthy lifestyle with its own specificity in the educational space of the institution of higher education acts as an urgent task of higher education, which must be solved due to new innovative approaches. The urgency of the questions raised is reflected in the format of a competency-based approach, where health issues are addressed in general and professional competences. Thus, a graduate with an educational qualification level "bachelor" must have the following general cultural competences:

- must be able to use methods of physical influence and self-education to increase the adaptation reserves of the body and promote health;

- use basic methods of protection against possible consequences of accidents, catastrophes, natural disasters.

In the field of pedagogical activity, it should ensure the protection of life and health of students in the educational process and during the study time.
Based on the above, the readiness to lead a healthy lifestyle should be considered as a complex integral condition characterized by the availability of knowledge, skills and skills in health care activities, which will encourage students' self-development and selfeducation, their adaptation in the context of higher education reform.

In the educational setting of a higher education institution, two conditions are required to manage the processes of nurturing readiness for a healthy lifestyle:

- it is necessary to know what causes or encourages the negative state of students;

- what practical actions can enhance the physical condition or eliminate the negative impact.

The effectiveness of the educational process for the formation of a healthy lifestyle depends on the conditions of its organization, where the traditional model leads to the emergence of constant stress, the destruction of mechanisms of self-regulation of physiological functions, the development of chronic diseases. Modeling a healthy lifestyle is ensured through the implementation of a wellness and educational program, which is a whole directed pedagogical activity to determine students' value orientations, such as: thoughts, views, ideas, beliefs, guidelines, feelings in the state of real importance for life. As a result, the formation of motivationalvalue attitude to health and leading a healthy lifestyle, increasing the level of literacy valeology and physical-health process, which ensures the systematic acquisition of motor skills, knowledge and knowledge, expanding the students' understanding of physical educa- 
tion. As a result of the implementation of such a program in a large part of the students decreases the level of morbidity, improves the functional and physical indicators of the organism, the focus on a healthy lifestyle is formed, confidence in their abilities is enhanced, and the emotional state is improved [4].

Tasks aimed at forming a healthy lifestyle for students within higher education institutions:

- expanding ideas about the content, principles and components of a healthy lifestyle;

- stimulation of activity, creative expression in matters of health and healthy lifestyle;

- formation of conscious, valuable and responsible attitude to health and healthy lifestyle;

- involvement in fitness activities;

- formation of motivation for a safe and healthy lifestyle;

- prevention of drug addiction, expansion of ideas about the negative impact of narcotic substances;

- developing the ability to withstand pressure and influence;

- learning the rules of safe behavior in public places, in transport;

- stimulation of activity, initiative, creativity in building individual lifestyles [5].

Teacher-oriented tasks:

1. Increasing the level of personal and professional competence in health issues.

2. Formation of motivation for maintaining one's health.

3. Development of teachers' creative potential.

4. Educating educators in the prevention of emotional burnout syndrome.
5. Provision of information on modern approaches to the structure and content of a healthy lifestyle.

6. Incentives to the creation and implementation of innovative developments in the program field.

7. Generalization and dissemination of positive experiences.

To implement the above in educational practice it is necessary to apply the following methods:

- organization of fitness activities;

- analysis of the health infrastructure of the institution of higher education;

- methodical and educational activity on forming attitude to healthy lifestyle;

- medical monitoring of students' health.

Accordingly, the formation of healthy lifestyles of students in the process of becoming them as a future specialist is a priority of higher education. At the same time, the educational paradigm is realized through a competent approach and provides for the strengthening of students' physical, psychological and social health and the formation of values of healthy and safe lifestyles in them [6]. This, in turn, requires higher education institutions to prepare students for the following tasks:

- formation of sustainable motivation for health students and teaching them to healthy life;

- organization of healthy educational environment;

- teaching healthy pedagogical technologies;

- to instill in students a general culture and an integral part, a health culture. 
To implement the program in higher education institutions for the formation of healthy lifestyles it is possible to apply the following methods:

- organizational construction of sports club activity, which in its content will be opened, self-managed, variational, which will allow to create a wellness and educational environment that will satisfy the needs of students for physical improvement on the basis of informal communication. The work of clubs and sports sections is planned taking into account the differential approach, the definition of a reference group, which will be the bearer of the rules and regulations of a healthy lifestyle;

- in accordance with the order on sports and mass work of conducting competitions in the format of higher education institution by main sports. Involvement in such competitions helps students to form in them the personal qualities that are necessary for future professional activity;

- taking into account the interests of students in sports and systematic physical training for the complex development of physical and mental qualities;

- educational work on the capabilities of the human body, its peculiarities of functioning, the relationship of physical and psychological, as well as spiritual health of the individual;

- development of an outreach system aimed at enhancing students' motivation for healthy lifestyles.

The use of such a mechanism contributes to:

1. increasing the interest of young people in physical perfection, revealing the value of physical culture;
2. promotion of independent preparation of students with wide use of natural factors;

3. formation of a vital need for physical education in the minds of students.

As a result of increasing the effectiveness of information and educational facilities of the institution of higher education in the formation of the need for student youth in constant exercise in physical culture and sports, as well as maintaining a healthy lifestyle, it is necessary to ensure:

- promotion of the importance of sports activities and the diversity of physical culture in the education and development of personality, in terms of intellectual, spiritual and moral development of the individual;

- systematic coordination of the work of all sources of information on the promotion of physical culture and sports;

- regularity, systematicity, continuity of the propaganda process, preservation of continuity of the given influence, combination of various forms of propaganda and educational activity with physical education and sports work in the institution of higher education;

- active encouragement and various satisfaction of interests and needs of student youth in physical and fitness activity within the framework of activity of higher education institution;

- teaching students of different forms and methods of promotion of physical culture and sports among different population groups and categories.

The basic principles of the advocacy campaign are:

- public access, that is, the opportunity for every student in a higher edu- 
cation institution to participate in promoting a healthy lifestyle, regardless of fitness level and health;

- diversity of choice of types of physical activity, forms and their organization during sports events;

- effective improvement of physical fitness, increase of vitality and increase of vital activity, carrying out interesting leisure;

- mobility, which is ensured with the emergence of new types of physical and fitness classes and trendy areas of higher education institution sports activities;

- the principle of activity in which young people are encouraged to include physical education and sports in their lifestyles.

Conclusions and prospects for further research. Today, it is especially important to adjust the existing stereotypes of behavior, to form motives for healthy lifestyles, and it is advisable to refocus the educational process on the cultivation of qualities, somehow characterizing the degree of involvement in healthy lifestyles.

Today the problems of forming a culture of healthy lifestyle of student youth as a basic element of mobility, competitiveness and moral maturity of an individual, an indicator of their readiness for active life in modern conditions remain unexplored.

Summarizing the above, it should be said that the need to form a healthy lifestyle for the future specialist as one of the strategic areas of training in higher education requires the question of considering the opportunities of the educational process to ensure such an event and attitude to its future ac- tivities that determine its value. to a healthy lifestyle.

\section{REFERENCES}

1. Vavreniuk S. A. (2018). Mehanizm mobilnosti studentiv yak zasib pidvishennya yakosti osviti v Ukrayini [The mechanism of student mobility as a means of improving the quality of education in Ukraine]. Publichne upravlinnya ta administruvannya v Ukrayini: naukovij zhurnal - Public Administration and Administration in Ukraine: a scientific journal, 8, 23-27 [in Ukrainian].

2. Pantyuk I. V. (Eds.) (2018). Current problems in the formation of a healthy lifestyle among students: materials of the International Scientific-Practical Internet Conference, May 16-17, 2018, Minsk, Belarus [in Russian].

3. Vavreniuk S. A. (2018). Udoskonalennya form i metodiv motivaciyi studentiv do zanyat fizichnoyu kulturoyu ta sportom pid chas navchannya u ZVO [Improvement of forms and methods of motivation of students to exercise in physical culture and sports during studying in ZVO]. Visnik Nacionalnogo universitetu civilnogo zahistu Ukrayini: zb. nauk pr. - Bulletin of the National University of Civil Defense of Ukraine: Coll., 1 (8), 542 [in Ukrainian].

4. Kolesov D. V. (2018). Zdorove cherez obrazovanie. [Health through education]. Biologiya v shkole - Biology at school, 2, 20-22 [in Russian].

5. Madzhuga A. G., Mamadiyarov M. D., Tkachenko S. V. (2003). Formirovanie valeologicheskoj kultury $\mathrm{v}$ kontekste sovmestno-dialogicheskoj zdravotvorcheskoj deyatelnosti subektov obrazovatelnogo processa [The formation of the valueological culture in the context of jointly dialogical healthimproving activities of the subjects of the educational process]. Valeologiya Valeology, 12, 58-61[in Russian]. 
6. Artyuhova T. Yu. (2015), Adaptacionnye vozmozhnosti kak pokazatel psihologicheskogo zdorovya uchastnikov obrazovatelnogo processa [Adaptation opportunities as an indicator of the psychological health of participants in the educational process]. Sibirskij psihologicheskij zhurnal - Siberian Psychological Journal, 13, 34-42 [in Russian].

\section{СПИСОК ВИКОРИСТАНИХ} ДЖЕРЕЛ

1. Вавренюк C. А. Механізм мобільності студентів як засіб підвищення якості освіти в Україні / С. А. Вавренюк // Публічне управління та адміністрування в Україні: науковий журнал, ПУ "Причорноморський науково-дослідний ін-т економіки та інновацій”, 2018. Вип. 8. С. 23-27.

2. Современные проблемы формирования здорового образа жизни у студенческой молодежи: материалы Международной научно-практической интернет-конференции, 16-17 мая 2018 г., Минск, Беларусь / БГУ, Фак. социокультурных коммуника- ций, Каф. экологии человека;редкол.: И. В. Пантюк (отв. ред.) [и др.]. Минск: БГУ, 2018. 277 с.

3. Вавренюк C. A. Удосконалення форм і методів мотивації студентів до занять фізичною культурою та спортом під час навчання у ЗВО / С. А. Вавренюк // Вісн. Нац. ун-ту цивільного захисту України: зб. наук пр. Х: Вид-во НУЦЗУ, 2018. Вип. 1 (8). 542 с. (Серія “Державне управління").

4. Колесов Д. В. Здоровье через образование // Биология в школе. 2018. № 2. C. $20-22$.

5. Маджуга А. Г., Мамадияров М. Д., Ткаченко С. В. Формирование валеологической культуры в контексте совместно-диалогической здравотворческой деятельности субъектов образовательного процесса // Валеология. 2003. № 12. С. 5861.

6. Артюхова T. Ю. Адаптационные возможности как показатель психологического здоровья участников образовательного процесса // Сибирский психологический журн. 2015. № 13. C. 34-42. 